\section{Commentary: Lymphatic fluid flows uphill in both hemispheres - and leaks in the same places}

\author{
Ronald K. Woods, MD, PhD, and \\ Viktor Hraska, MD, PhD
}

Sharma and colleagues ${ }^{1}$ provide a comprehensive description of protein-losing enteropathy (PLE) and plastic bronchitis (PB) in patients with Fontan circulation-yet another testament to the utility of their Fontan registry. In a cohort of 1561 patients spanning 4 decades, the authors report 48 patients with PLE only, 4 with PB only, and 3 with both. Right ventricular morphology with hypoplastic left heart syndrome (hazard ratio [HR] of 2.3), prolonged effusion after the Fontan (HR of 2.4), and older age at Fontan (2-year increment, HR of 1.13) were associated with development of PLE/PB, whereas once PLE/PB was diagnosed, only older age at Fontan was associated with death or transplant (HR of 1.23). Five-year freedom from death or transplant was $70 \%$. The authors employed the full gamut of medical and classical surgical options, the results of the latter apparently not highly appealing.

The authors' results lead really to only one explicit actionable item-do the Fontan at an earlier age (median age in their cohort was 4.6 years). However, an HR of only 1.1 for a 2-year increment implies minor impact, particularly for programs already doing Fontan procedures in patients in the 2- to 3-year old age range. The fact that hypoplastic left heart syndrome was present in only $13 \%$ of their patients, in contrast to nearly $50 \%$ at our institution, for example, may also hinder translation of results to other institutions.

\footnotetext{
From the Division of Pediatric Cardiothoracic Surgery, Herma Heart Institute, Children's Wisconsin; and Department of Surgery, Medical College of Wisconsin, Milwaukee, Wis.

Disclosures: The authors reported no conflicts of interest.

The Journal policy requires editors and reviewers to disclose conflicts of interest and to decline handling or reviewing manuscripts for which they may have a conflict of interest. The editors and reviewers of this article have no conflicts of interest.

Received for publication Aug 11, 2020; revisions received Aug 11, 2020; accepted for publication Aug 11, 2020; available ahead of print Aug 15, 2020.

Address for reprints: Ronald K. Woods, MD, PhD, Division of Pediatric Cardiothoracic Surgery, Children's Wisconsin, 9000 W Wisconsin Ave, MS B 730, Milwaukee, WI 53226 (E-mail: rwoods@chw.org).

J Thorac Cardiovasc Surg 2021;161:2166-7

$0022-5223 / \$ 36.00$

Copyright (c) 2020 by The American Association for Thoracic Surgery

https://doi.org/10.1016/j.jtcvs.2020.08.031
}

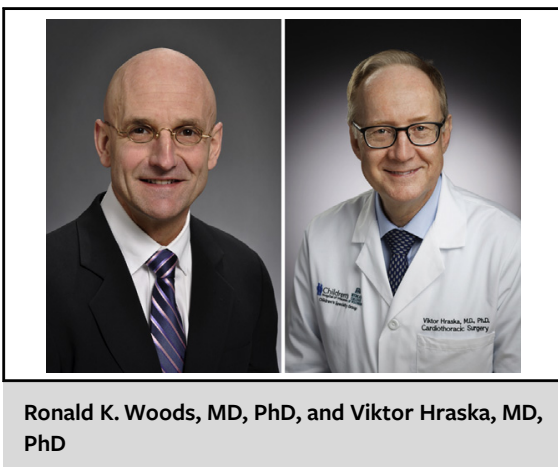

CENTRAL MESSAGE

In Australia and New Zealand,

hypoplastic left heart syndrome, older age at Fontan, and prolonged pleural effusion appear to be risk factors for protein-losing enteropathy and plastic

bronchitis.

Nevertheless, their report is a very detailed and comprehensive addition to the literature, and we thank them for it.

As a specialty, we continue to improve our understanding of these conditions-far from perfect, but getting better. Thoracic duct flow in the Fontan is considerably greater than in the normal circulation. We are asking it to drain to a venous system at greater pressure than normal. In some patients, the anatomy of the lymphatic system may be abnormal. It's akin to hooking up a pump to a garden hose (which may be prone to leak), setting the pump on high, and putting your foot on the drainage end. Something has to give. An infection or other insult may provoke the leak earlier in certain patients, whereas in others, antecedent factors seem absent. The fact that more patients with Fontan circulation don't develop PLE/PB is a testament to the remarkable adaptability of the human body. Decompression of the thoracic duct to the lower pressure atrial or pulmonary venous system seems appealing-in theory. ${ }^{2,3}$ Whether therapeutic or preemptive (in high-risk patients) decompression is durably effective remains to be seen. While thoracic duct occlusion (by any means) seems highly inadvisable, there is value to embolization of smaller tributaries documented to be the source of leak. ${ }^{4}$ Also, we speculate the latter may enhance efficacy of therapeutic decompression as pressure in a leak basin may be (likely is) lower than that in the atrium-decompression alone 
may not stop the leak. Fortunately, whatever we learn of these "newer" therapies will be true in both hemispheres-the Coriolis effect is not in play.

\section{References}

1. Sharma VJ, Iyengar AJ, Zannino D, Burchill L, Cordina R, d'Udekem Y, et al. Protein-losing enteropathy and plastic bronchitis after the Fontan procedure. J Thorac Cardiovasc Surg. 2021;161:2158-65.e4.
2. Hraska V, Mitchell ME, Woods RK, Hoffman GH, Kindel SJ, Ginde S. Innominate vein turn-down procedure for failing Fontan circulation. Semin Thorac Cardiovasc Surg Pediatr Card Surg Ann. 2020;23:34-40.

3. Smith CL, Hoffman TM, Dori Y, Rome JJ. Decompression of the thoracic duct: a novel transcatheter approach. Catheter Cardiovasc Interv. 2020;95: E56-61.

4. Dori Y, Keller MS, Rome JJ, Gillespie MJ, Glatz AC, Dodds K. Percutaneous lymphatic embolization of abnormal pulmonary lymphatic flow as treatment of plastic bronchitis in patients with congenital heart disease. Circulation. 2016; 133:1160-70.
See Article page 2158.

\section{Commentary: Late adverse outcomes of the Fontan circulation: A PLEa for standardization of diagnostic criteria}

\author{
Adam M. Lubert, MD, ${ }^{\mathrm{a}, \mathrm{b}}$ and \\ Andrew N. Redington, $\mathrm{MD}^{\mathrm{a}}$
}

Protein-losing enteropathy (PLE) and plastic bronchitis (PB) are 2 of the most feared complications in those with a Fontan circulation. ${ }^{1,2}$ Although treatment options for each exist, the success of medications and procedural interventions is often only transient, with only heart transplantation offering the possibility of long-term cure. However, late referral for transplant after months or years of hypoalbuminemia due to PLE may make patients ineligible for transplantation or at increased risk of waitlist

\footnotetext{
From the ${ }^{a}$ Department of Pediatrics, Cincinnati Children's Hospital Heart Institute, University of Cincinnati College of Medicine; and ${ }^{\mathrm{b}}$ Cincinnati Adult Congenital Heart Disease Program, Cincinnati Children's Hospital Medical Center, Cincinnati, Ohio.

Disclosures: Dr Lubert participates in multicenter Fontan research supported by Mezzion Pharma Co Ltd. Dr Redington reported no conflicts of interest.

The Journal policy requires editors and reviewers to disclose conflicts of interest and to decline handling or reviewing manuscripts for which they may have a conflict of interest. The editors and reviewers of this article have no conflicts of interest.

Received for publication Aug 18, 2020; revisions received Aug 18, 2020; accepted for publication Aug 18, 2020; available ahead of print Aug 24, 2020

Address for reprints: Adam M. Lubert, MD, Cincinnati Children's Hospital, 3333 Burnet Ave, MLC 2003, Cincinnati, OH 45229-3026 (E-mail: adam.lubert@ cchmc.org).

J Thorac Cardiovasc Surg 2021;161:2167-8

$0022-5223 / \$ 36.00$

Copyright (C) 2020 by The American Association for Thoracic Surgery

https://doi.org/10.1016/j.jtcvs.2020.08.052
}

Check for updates

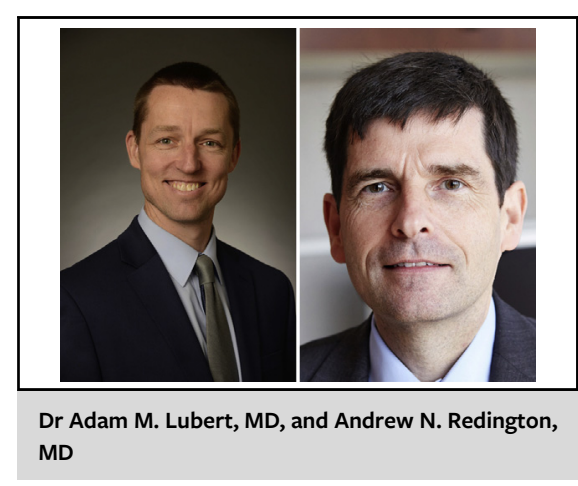

CENTRAL MESSAGE

The lack of universally applied diagnostic criteria makes this study's incidence of post-Fontan PLE and plastic bronchitis of $5 \%$ at 30 years difficult to compare with other reported series.

and perioperative mortality. Consequently, defining the mechanisms underlying the evolution of PLE and PB (which although often lumped together are clearly very different diseases), improved understanding of the factors that predict success or failure of medical treatments, and better prediction of the optimal timing of referral for transplantation are crucial to improving care of these, and other, adverse sequelae of the chronic Fontan state.

In this issue of the Journal, Sharma and colleagues ${ }^{3}$ provide a retrospective review of patients with a Fontan circulation diagnosed with PLE and/or PB using the Australia and New Zealand Fontan Registry. Previous reports from this registry have enriched our understanding of long-term Fontan outcomes, and the current study aims to identify associations with PLE/PB diagnosis and 